\title{
A tragédia revisitada: uma nova mî(me)se en cène no teatro de Nelson Rodrigues
}

\author{
The tragedy revisited: a new mîl(me)se \\ en cène in the Nelson Rodrigues's theatre
}

João Felipe Barbosa Borges ${ }^{1}$

\begin{abstract}
Resumo: A obra de Nelson Rodrigues gira em torno de alguns temas centrais, como amor e morte, sexo e traição, violência e transgressão que, desgastados no cenário teatral europeu e brasileiro, frequentemente apagam seu caráter de originalidade. Contudo, talvez não seja pelo conteúdo, mas pela forma, que o dramaturgo atinja a sua maior inovação. Isso, porque traz ao palco uma tragédia que, ao mesmo tempo em que rejeita seu modelo fundador, rejeita também a tragédia produzida entre os anos de 1880 a 1950, com raras exceções (a exemplo de Brecht, Hauptmann e Pirandello), ainda presa aos preceitos clássicos de objetividade, realidade e verossimilhança, senão nos temas, ao menos na estruturação formal dos conteúdos. Nesse sentido, pretendo identificar, em Vestido de noiva, elementos que afastam a peça rodrigueana do modelo de tragédia tradicional, e instauram uma nova mîse en cène no teatro brasileiro, liberta da prisão formal que representou durante tanto tempo o desejo do real.
\end{abstract}

Palavras-chave: Teatro brasileiro. Tragédia. Mîse en cène. Nelson Rodrigues. Vestido de noiva.

\begin{abstract}
The work of Nelson Rodrigues focuses on a few central themes, such as love and death, sex and betrayal, violence and transgression, which, worn in the European and Brazilian theater, often minimizes its character of originality. However, it is in the form - and not in the content - that the playwright reaches its greatest innovation, bringing to the stage a tragedy which, while rejecting its founder model, runs counter to a tragedy, between the years 1880-1950, with rare exceptions (like Brecht, Hauptmann and Pirandello), still attached to the classical principles of objectivity, reality and verisimilitude, maybe not in the contents, but at least in the formal structuring of contents. Thus, I intend to identify, in Vestido de noiva, how the Nelson Rodrigues's work moves away from the traditional model of tragedy, introducing a new mîse en cène in the Brazilian theater, finally released from the formal prison that represented, for a long time, the desire of real.
\end{abstract}

Keywords: Brazilian theater. Tragedy. Mîse en cène. Nelson Rodrigues. Vestido de noiva.

"Não a luz, o iluminado".

(Goethe)

\section{- Luz, câmera, ação!}

Esperem um pouco, mas para onde a câmera se dirige? Aliás, é de teatro que falamos aqui! Para onde o nosso olhar se dirige? O cenário é dividido em três planos: alucinação, memória e realidade. "Quatro arcos no plano da memória; duas escadas laterais. Trevas" (RODRIGUES, 1977, p. 9). No plano da realidade, “a buzina de um automóvel. Rumor de derrapagem violenta. Som de vidraças partidas. Silêncio. Assistência.
Silêncio" (RODRIGUES, 1977, p. 9). Médicos. Jornais. No plano da alucinação, "Alaíde (nervosa): Clessi... Clessi... Quero falar com Madame Clessi” (RODRIGUES, 1977, p. 9). No plano da memória: Casamento. Enterro. A mulher de véu. Pedro. Ainda Alaíde. "É casada? Não sei" (RODRIGUES, 1977, p. 14).

- Corta! Corta! - o leitor, como diretor deste espetáculo que por ora vos apresento, provavelmente o dirá. Afinal, onde está o teatro como palco de todo processo do real? Ou ainda, a única realidade tout court...? Não! Não é isso que parece acontecer aqui. Mas, gostaria de vos adiantar que este pequeno resumo 
da peça Vestido de noiva (1943), de Nelson Rodrigues, corpus deste artigo, não é muito diferente da situação inicial em que a peça, na íntegra, exibe, isto é, não há um contexto prévio, uma introdução ou algum argumento que apresente as personagens ou, no mínimo, as explique. Mas, quero resumir brevemente seu contexto para facilitar ao leitor a compreensão da leitura seguinte, uma vez que pretendo, como já pelo título insinuei, argumentar em favor do reconhecimento de uma nova mîse en cène e um novo tipo de tragédia que se configuram na obra de Nelson Rodrigues.

Esta mulher atordoada com quem nos deparamos logo de início, aflita à procura de Madame Clessi, é Alaíde. Sua aflição reside em algum acontecimento que, contudo, desconhece. E é em torno do percurso que Alaíde fará do esquecimento à lembrança e à consequente revelação não só do acontecimento em si, como dos que nele estão envolvidos, que a peça girará. A personagem transitará entre três planos, que no decorrer do espetáculo irão se entrecruzar, e por vezes até se fundir. No plano da realidade, que dá início à peça, após a buzina de automóvel, a derrapagem e o som das vidraças se quebrando, será revelado o acidente de uma mulher, que entre os enfoques dos noticiários e a mesa de cirurgia, descobriremos morta. No plano da alucinação, encontraremos Alaíde à procura de sua heroína, Madame Clessi, prostituta do início do século XX, que fora assassinada por um amante adolescente e por quem, desde que encontrou o diário, Alaíde se encantara. E, finalmente, no plano da memória, concentraremo-nos no esforço da personagem de relembrar, na companhia de Madame Clessi, as pessoas e os acontecimentos que, fragmentária e confusamente, vão lhe surgir nas imagens de um homem, uma mulher de véu, um casamento, um enterro, além de esporádicas recordações de outras épocas e outras histórias.

Ora, isso bastará ao leitor, se conhecedor da obra de Nelson Rodrigues ou mesmo das inúmeras declarações da imprensa a seu respeito, para que reconheça o palco armado ao desfecho daquelas tragédias familiares tão ao seu gosto, como a recorrência de temas como amor e morte, sexo e traição, violência e transgressão, no seio familiar, explorados exaustivamente em suas obras, pode evidenciar (BATALHA, 2007). E seguindo esse contexto de obsessões, não será surpresa que Alaíde descubra que o homem e a mulher de véu, que inicialmente não consegue identificar, sejam seu marido, Pedro, e sua irmã, Lúcia. Natural também que Pedro e Lúcia, como amantes, andassem a planejar a morte de Alaíde, que se descobrirá, ela própria, a vítima fatal do acidente que, simultaneamente, no plano da realidade, cruza-se a suas recordações. Logo, esclarecido estará o enterro e o casamento que se dão no plano do real: o enterro é de Alaíde, e o casamento, de sua irmã e seu marido.

Assim, estaria, com o fim da peça, o mistério desvendado, e a crítica do dramaturgo exposta, a revelar não só toda a hipocrisia das instituições sociais do casamento e da família, marcadas pelos desejos proibidos, pelo adultério e pela deslealdade, como também a própria ironia do título, que dessacraliza a simbologia instituída religiosa e socialmente a um vestido de noiva, geralmente associado à pureza, castidade e fidelidade. Nesse sentido, pouca inovação traria Nelson Rodrigues ao teatro brasileiro para além dos temas folhetinescos e melodramáticos, que como salienta Iná Costa (1997, p. 74), "se exposto aos franceses dos anos trinta em formato de peça bem-feita, soaria como desgastado lugar comum do velho teatro realista dos adultérios e das mondaines" E nem mesmo a nós brasileiros, sua peça soaria como novidade: já em 1919, Roberto Gomes escrevia A Casa fechada, na qual o adultério de uma mãe de família desmascara, como em Vestido de noiva, os descaminhos das instituições sociais; tema que mais tarde, nos anos de 1930, também retomarão autores como Renato Viana, Paulo de Magalhães e Joracy Camargo, por exemplo, que trarão ao palco, inclusive, precedendo o teatro rodrigueano, questões relacionadas ao incesto, à loucura e à transgressão.

Destarte, pouca relevância teria de se estudar o que afasta Vestido de noiva da tragédia que o modelo grego pressupõe, pois tal como as tragédias de seu tempo, embora inovasse na temática, pouco modificaria no que diz respeito à forma de representação, pois 
tal como Aristóteles $\left(1997^{2}\right)$, em sua Poética, exigia, teríamos aí a representação de uma ação grave: o assassinato; de alguma extensão, de modo que a memória a poderia abranger inteira; não em linguagem exornada, é certo - pelo menos não no sentido que Aristóteles imprimia ao termo -, e tampouco a representar seres em tudo superiores aos da atualidade. Mas quê! Ao menos Alaíde, à semelhança daquele Édipo de Sófocles, não é tão perversa a ponto de sua desgraça despertar menos pena que justiça, e nem tão virtuosa a ponto de seu destino provocar em nós indignação (lembremos que, na peça, se sua morte foi assassinato ou não, é um mistério; e ela, em todo caso, também havia roubado o namorado da irmã, tendo a devida punição, se não pelas mãos desta, ao menos pelas mãos do destino). De qualquer modo, se a finalidade da tragédia seria, por meio das ações representadas, "inspirando pena e temor, operar a catarse própria dessas emoções", e se "em tudo", como o próprio Aristóteles o dirá, "a finalidade é o que mais importa" (ARISTÓTELES, 1997, p. 24-25), pode-se dizer que Vestido de noiva atingiu sua pretensão.

Nesse sentido, creio que poderíamos nos perguntar até, a respeito da peça rodrigueana e da tragédia grega, o mesmo que se perguntava Georg Lukàcs (2000) ${ }^{3}$ sobre os romances de Dostoiévsky e as epopeias, isto é, se os romances do escritor não seriam as epopeias do futuro: não seria, então, Vestido de noiva nossa tragédia do futuro, com alguma inovação, porém, no que diz respeito aos conteúdos históricos, às origens da personagem e sobretudo à linguagem? Sobre um período anterior, aliás, Peter Szondi (2001), ao estudar a alteração do quadro estético teatral entre os anos de 1880 e 1950, já identificava a continuidade do gênero trágico no teatro, destacando que somente o conteúdo representado nos palcos era histórico, concernente às mudanças do tempo, mas a forma, a estruturação desse conteúdo, era atemporal: continuávamos, com raras exceções (a exemplo de Brecht, Hauptmann e Pirandello), a repetir uma estrutura que, na verdade, nos acompanhava desde as tragédias gregas, ainda presos à verossimilhança, à edificação (advinda do determinismo e da correção moral), e à tentativa de tornar mesmo o impossível, passível de creditação.

Contudo, se a tragédia entra novamente em cena em Vestido de noiva, não parece ser nos moldes daquela que Sófocles exemplarmente consolidou, e tampouco nos moldes que nosso teatro de estética realista só fez por repetir. Podemos começar pela própria constituição do herói. Lembremos que na tragédia prototípica, segundo a ótica aristotélica, o herói, além de necessariamente superior às pessoas de seu tempo, deveria ocupar uma posição intermediária, não sendo nem essencialmente bom, nem essencialmente mau, justamente para que inspirasse nos espectadores pena e temor, ao invés de indignação e justiça:

Como a estrutura da tragédia [...] deve consistir na imitação de fatos inspiradores de temor e pena - característica própria de tal imitação - em primeiro lugar é claro que não cabe mostrar homens honestos passando de felizes a infortunados (isso não inspira temor nem pena, senão indignação); nem os refeces, do infortúnio à felicidade (isso é o que há de menos trágico: falta-lhe todo o necessário, pois não inspira nem simpatia humana [...]; tampouco o indivíduo perverso em extremo tombando da felicidade no infortúnio; semelhante composição, embora pudesse despertar simpatia humana, não inspiraria pena, nem temor (ARISTÓTELES, 1997, p. 31-32).

Resta o herói em situação intermediária, que é "aquele que nem sobreleva pela virtude e justiça, nem cai no infortúnio em conseqüência de vício e maldade, senão de algum erro" (ARISTÓTELES, 1997, p. 32), erro que, no entanto, de maneira nenhuma se pode confundir com uma falta moral, pois o tipo de falta que "necessitamos para a tragédia ideal de Aristóteles é uma certa forma profunda de ignorância que conduz a consequências desastrosas sem subverter a integridade moral do herói" (PEREIRA, 2008, p. 26), ou, nas próprias palavras do autor, o

Originalmente escrita entre os anos de 334 e 330 a.C.

3 A publicação original data de 1915. 
herói não poderia, por seu erro, deixar de figurar "entre aqueles que desfrutam de grande prestígio e prosperidade" (ARISTÓTELES, 1997, p. 32), caso contrário, não seria exemplar. Assim, os heróis trágicos, como seres superiores, de grandes feitos e belas palavras, poderiam até cometer excessos, perder o prumo, mas não sem retornar ao que de fato eram: heróis. Mesmo seus erros eram senão marcados, ao menos perdoados pela altivez: vide Édipo, que cometeu seus excessos sem saber (e, ora, pecar sem saber não é pecar!), e mesmo assim aceitou a punição do destino em favor dos seus, uma vez que se Tebas vivia sob o infortúnio, era porque seu rei havia se casado com a mãe e matado o próprio pai. E é isso que tanto nos aterroriza quanto nos comove, fazendo de Édipo o herói paradigmático do trágico para Aristóteles: "paga[r] o preço de uma falta que cometeu sem saber", "paga[r] simplesmente o preço de seu não saber" (LACOUE-LABARTHE, 1986, p. 210 apud VIDAL, 2014) ${ }^{4}$.

Mas o fato é que se a vista dos feitos de um herói paradigmático como Édipo é valorativa de sua virtude moral, apesar de sua grande falta, com Alaíde não é isso que parece ocorrer: não era soberana aos demais, e tampouco virtuosa a ponto de ser capaz de abdicar de um reino em favor de qualquer pessoa. Em verdade, ela não é capaz nem mesmo de abdicar de seus próprios desejos e vontades pela irmã, que carregava seu sangue. Sua personalidade é cambiante, inclusive moralmente cambiante. Ora será a mulher dissimulada que rouba o namorado da irmã. Ora será a rapariga ingênua que não sabe das traições e do caráter do marido. E o que dizer da mulher lasciva e desejante, que tem como ídolo uma prostituta amante de um adolescente? Não nos esqueçamos também da rapariga amável, sempre doce, com voz lenta e velada, que em um rompante, passa à mulher excitada, sardônica, cortante, a esbofetear qualquer um que lhe contrarie. Enfim, o que forma esta nossa Alaíde são sentimentos antagônicos, que revelam uma tensão permanente entre o amor por um homem que não sabe se odeia por tão bom, ou por ter podido planejar-lhe a morte; entre a culpa de ter roubado o namorado da irmã, e o prazer advindo desse seu pequeno delito; entre o desejo de permanecer ligada ao marido e o desejo de transgredir à ordem moral, social e familiar.

Enfim, é esta espécie de dialética entre amor e ódio, prazer e culpa, ordem e transgressão, que afasta Alaíde de Édipo. Isso porque a ambiguidade e a tensão desejáveis ao herói grego para produzir o efeito catártico no espectador não deveriam transgredir a ordem moral. Auerbach, em "A cicatriz de Ulisses" (2004), ao comparar o texto épico e o texto bíblico, ressalta a debiedade do elemento de tensão na cultura grega, sempre suplantado pela descrição clara e inteiriça dos acontecimentos, pela predominância do primeiro plano narrativo ou de ação, sempre suplantado pela existência de uma ordem anterior a quaisquer conflitos, sejam conflitos internos, ou conflitos entre os homens e o mundo, ordem que precisaria, a todo custo, ser restaurada caso corrompida. Caberia ao herói apenas se sacrificar para recuperar a medida e a harmonia perdidas. Já Alaíde, nascida em uma temporalidade outra, não consegue enxergar harmonia possível. Não estava mais em desarmonia com o mundo como a morta que recorda suas lembranças e investiga seu passado, do que como a Alaíde viva, sempre marcada pelo prazer do amor e da ordem familiar e pela culpa do pecado que transpassava todo aquele triângulo amoroso e a ela própria. No seu caso, não há nenhuma situação de fortuna em que se considere completamente feliz e que se passe à infelicidade, e nesse sentido é que estará muito mais próxima à heroína problemática de que nos fala Lukács (2000) do que à heroína no seu sentido tradicional: problemática não só porque, como personagem inconclusa e aberta, é detentora de valores ambíguos, que ao mesmo tempo em que a elevam, a destituem do papel de herói, mas também e principalmente, porque não enxergando harmonia possível entre homem e mundo, será uma eterna "trovadora", estando sempre em busca de algo que lhe possa com-

4 VIDAL, Paulo. Édipo sem complexo, Hamlet edípico. ECOS - Estudos Contemporâneos da subjetividade, Niterói, v. 4, n. 1, p. 76-89, 2014.

5 No sentido etimológico do termo, originado do francês trouver - em português, achar, encontrar. 
pletar: no plano presente, buscará a resolução de suas dúvidas acerca do acontecido, e por conseguinte, da própria identidade; no plano passado, memorialístico, solteira, quererá casar-se contrariando à irmã, e casada, quererá fugir, trair, se transformar em uma Madame Clessi. Em todos os casos, estava sempre insatisfeita, em conflito com o mundo.

Nesse sentido, Alaíde se afastará do gênero trágico prototípico não apenas porque é marcada pela imoralidade, imperdoável ao herói trágico ideal. Esse afastamento, aliás, já havia sido ensejado mesmo no século XIX, quando contrariando os ideais de nacionalização e idealização romântica, a geração realista buscou levar aos palcos a decadência e o submundo. No caso de Alaíde, ela se afastará do herói trágico ideal também e, sobretudo, porque se a dubiedade e a tensão eram, no sentido que Auerbach (2004) atribui ao termo, elementos débeis entre os gregos, assim como entre muitos de nossos heróis oitocentistas (não é à toa que o século XIX será o auge das personagens-tipo), na personagem rodrigueana essa dubiedade será seu princípio formador. Sua ótica não é a shakespeariana calcada na exclusividade do to be or not to be, mas talvez àquela que o nosso Guimarães Rosa já ensinara em seu Grande Sertão: “Tudo é e não é” (ROSA, 1958, p. 13), porque ela sabe que cada perfil tem dois lados... Ela mesma o poderia provar. E por isso não poderá se fechar na definição de uma identidade: o ser humano é ambíguo, aberto e volúvel. O próprio transitar de Alaíde entre os vários planos de ação da peça e entre os vários tempos, o evidenciam. Não é somente o rememorar como fim, mas como processo, que enquanto tal, pode revelar a volubilidade de cada um: quem seria afinal "a pervertida" (RODRIGUES, 1977, p. 74)? Alaíde, que roubou o namorado de Lúcia? Lúcia, que manteve um caso com o marido da irmã? E "a idiota, ingênua” (RODRIGUES, 1977, p. 75)? Seria de fato a primeira que, nas palavras da irmã, ignorou o caráter do marido? Ou seria a própria Lúcia, que deixou Alaíde roubar-lhe o namorado? Para essa nossa heroína, como para todas as suas personagens, ser definido será o mesmo que ser morto. Talvez seja por isso que Alaíde se descubra morta quando consegue descobrir e completar o enigma do que lhe aconteceu. Mas, ora, será que o enigma fora de fato completado? O que houve com Alaíde? Seu atropelamento foi um acaso do destino? Suicídio? Assassinato? Quem a matou, ou quem mandou-lhe matar?

Iná Costa (1997) chegará a uma conclusão sobre esse enigma ao analisar comparativamente as peças Vestido de noiva e L'Inconnue d'Arras (1935), do dramaturgo francês Armand Salacrou - peça na qual, segundo a autora, foi baseada a obra de Nelson Rodrigues:

Em Vestido de noiva Alaíde se mata (agora sabemos que é suicídio mesmo: pelo original e pela 'regra clássica' que concede aos suicidas o direito de rever sua vida) porque descobre que seu marido Pedro a trai com Lúcia, sua irmã. Nas duas peças temos o desfile das aventuras do suicida como enquadramento geral. Em outras palavras, o relato é uma espécie de exame de consciência (e do inconsciente) do protagonista morto (COSTA, 1997, p. 79).

O mistério da peça estaria, assim, esclarecido, já que, em L'Inconnue d'Arras, após o adultério da mulher Yolanda, Ulisses também se suicidará e começará sua rememoração. Contudo, mesmo que Rodrigues tenha se inspirado na peça de Salacrou, e uma série de semelhanças de linguagem e enredo lhes sejam identificadas, estaria por isso fadado a atribuir o mesmo destino de sua personagem ao destino daquela do dramaturgo francês? Isso não seria negar os próprios princípios da Literatura Comparada, que já pelos iniciais ensaios de Valéry $(1960)^{6}$, dava mostras de que o texto segundo não só reproduzia, como também atualizava o texto primeiro? E se Rodrigues dessacraliza, pelo contraste entre o título e a obra, a concepção religiosa que um vestido de noiva representa, por que não poderia fazer o mesmo com a "regra clássica do suicídio" a que Costa nos chama atenção? Fato é que essa é uma obra em que o princípio aditivo do

${ }^{6}$ A publicação original data de 1923. 
“Tudo é e não é” não se efetua somente no plano da constituição da personagem, mas no plano do próprio enredo, uma vez que a história renuncia qualquer possibilidade de leitura una, fechada, da qual se possa extrair uma única verdade.

Já Aristóteles admitia que verdade e falsidade não eram mesmo os termos corretos para se tratar de manifestações artísticas. Mas talvez aqui o termo verossimilhança também não seja o adequado, pelo menos não se tivermos em mente a noção de verossimilhança tal como a concebia o pensador, para quem um fato, para ser recebido como real, deveria ser a imitação de uma ação acabada e inteira, com princípio, meio e fim, afinal é na integridade e unidade do objeto que o autor poderia justificar o ficcional, e atribuir à sua mentira, ares de verdade. Diferentemente dos gregos, no entanto, se a tragédia retorna mais uma vez, não é sob a imanência de um realismo que, mesmo quando versava sobre o fantástico, visava à sua aceitação como real. Se tomarmos a comparação de Vestido de noiva com L'Inconnue d'Arras, por exemplo, veremos a diferença. A peça de Salacrou, embora retrate o fantástico ao trazer as recordações de um morto para o palco central, não deixa de pautar-se naquela mesma noção de verossimilhança aristotélica, que pretendia fazer verdade mesmo o impossível. Basta atentar que as recordações de Ulisses não surgirão tão caoticamente como no caso de Alaíde, e tampouco seremos lançados no acontecimento sob o mistério que circunda a peça rodrigueana. Tão logo ouviremos o tiro com que Ulisses se mata, o mordomo da casa explicará ao público que o seu patrão se matou em decorrência do adultério de sua mulher, e que mereceria segundo a "regra clássica do suicídio", rever toda a sua vida. Salacrou, nesse sentido, na sua justificativa, preservará quase rigorosamente a ordem grega, ainda que também apresente em sua obra a ocorrência de outros planos de ação que não o da memória. E nisso diferirá substancialmente Nelson Rodrigues, pois a situação de Alaíde não é introduzida por nenhum argumento ou mesmo explicada, renunciando, assim, a uma herança realista que, na estruturação dos acontecimentos, apenas disfarçava a ilusão criada.

Essa renúncia irá se construir principalmente a partir de duas perspectivas adotadas na peça: primeiro, através da falta de delimitação e contorno da situação e das personagens; e segundo, através da recuperação da memória, que, como a própria Alaíde admite, nunca lhe surge nítida: "Não me lembro, Clessi. Estou com a memória tão ruim! [...]” (RODRIGUES, 1977, p. 51) - impaciente com a própria memória, dirá. Mas partamos antes ao primeiro ponto: a falta de delimitação das situações e das personagens. Já vimos que Alaíde não se pode definir, delimitar, e tampouco poderá o fazer aos seus. É a dúvida mesma que a acompanhará: Quem é de fato Alaíde? O que realmente aconteceu? Não poderemos responder. E onde os desenlaces se passam? Também não seremos capazes. Não é como naquele Édipo, de Sófocles, onde tudo é descrito com exatidão e relatado com vagar: quando o Coro dos Anciãos de Tebas anuncia o lugar da encenação - diante do palácio do rei Édipo -, não deixa de dizer que "junto a cada porta [do palácio] há um altar, a que se sobe por três degraus" e que o "o povo está ajoelhado em torno dos altares, trazendo ramos de louros ou de oliveira" (SÓFOCLES, 2005, p. 21)7. Tudo é iluminado, nada é deixado em suspenso. Sabemos até que a porta do altar "se sobe por três degraus". Mas no caso de Alaíde, até o cenário é vazio. Ou quase. No palco, pouquíssimos móveis. E os "quatro arcos no plano da memória; duas escadas laterais" (RODRIGUES, 1997, p. 9). O restante: ou são invisíveis, ou estão sob a penumbra. A própria profusão dos três planos de ação e a ocorrência de uma Alaíde no plano da alucinação, que revisita os palcos da memória e da realidade já dificulta a percepção, por parte do espectador, do lugar de enunciação. Ademais, tudo é tão escuro, tão pouco iluminado. Notemos que o cenário se apresenta escuro, e apenas fachos de luz incidem sobre o plano de ação que se deseja enfocar, enquanto os demais ficam sob as trevas. Isso vem de encontro à mesma perspectiva de leitura da peça.

7 Originalmente escrita por volta do ano de 427 a.C. 
As coisas não se dão, como no teatro grego, onde a plasticidade das descrições e das falas davam a (falsa) impressão de que conhecíamos todos os acontecimentos por inteiro. O que os fachos de luz incididos apenas sobre os planos de ação enfocados implicam é que não enxergamos a luz, mas, para retomar a epígrafe de Goethe, apenas aquilo que nos é iluminado. Ou, em outras palavras, não se conhece a verdade; só aquilo que nos contam. É por isso que ao invés de preencher o nosso campo de visão com seu passado, presente e futuro, Alaíde tanto nos levará aos bastidores, quanto nos fechará a visão de seu pensamento, deixando-o em suspenso. É algo como se a peça revelasse assim, também através do recurso da iluminação, não a totalidade do campo dos fenômenos, mas apenas uma parte desse campo.

Ora, e a isto o próprio artifício de trabalhar com os mecanismos da memória só vem corroborar, porque se o seu espaço e o seu tempo não se podiam definir ou mesmo contornar, era porque, no terreno da memória, tempo e espaço são interiores e igualmente fragmentários. Claro que poderia se advogar que, no memorialismo difuso instaurado pela protagonista, poderíamos ver em Alaíde aquela mesma voz unívoca, tão cara ao teatro (e à arte em geral), que nos acompanha desde a Grécia Antiga e que nos faz pensar que a versão narrada é a versão real dos fatos, afinal, não deixa de transmitir uma visão parcial da realidade, uma vez que é ela quem detém a palavra. E de fato assim o seria se essa Alaíde não revelasse a plena consciência do caráter parcelar e da propensão seletiva da memória. Mas ela a revela, não tentando gerar quaisquer ilusões de real, porque sabe que "o notado procede do notável, mas o notável não é - desde Heródoto, quando a palavra perdeu sua acepção mítica - senão aquilo que é digno de memória, isto é, digno de ser notado" (BARTHES, 1988, p. 155), ou, nas suas próprias palavras, sabe que as lembranças chegam a ela encobertas por véus, e que na rememoração tudo "é uma misturada" (RODRIGUES, 1977, p. 80).

Quando o passado de Édipo vem à tona no plano narrativo da tragédia de Sófocles, este vai aos poucos tornando-se presente. É como se só existisse um plano temporal, onde mesmo as digressões deveriam se enquadrar. O jovem Édipo pode ter se casado com a mãe e matado o pai sem saber, mas isso lhe é revelado. E igualmente lhes são reveladas as razões que degradam sua sorte: tentar fugir a uma imposição do Destino. Nada é deixado em suspenso, escondido. Tudo tem um passado, presente e futuro determinado, tudo é justificado e todos os tempos são trazidos à luz como se de presente se tratassem. O mesmo se dá na peça de Salacrou quando o mordomo explica ao espectador o que irá acontecer. É uma forma de não se eximir do real em sua digressão. Contudo, com Alaíde é eminentemente diferente. É uma ideia de tempo determinada por sua vontade, na qual o passado se apresenta tão ou mais irrevogável que o presente; é um tempo multíplice que, pela própria multidivisão da personagem, acaba por se dividir não só em diferentes planos de ação, como também em diferentes tempos de ação dentro de um mesmo plano. Basta que vejamos, a exemplo, a gama de passados possíveis que recupera: há tanto a recuperação de uma Alaíde apaixonada e ingênua, como a recuperação de uma Alaíde capaz de matar o próprio marido e desejosa de uma transgressão. Sem contar as recuperações enganosas que a levam a crer que matou o marido e não o contrário, e que mistura o seu plano memorialístico com o plano de realidade de madame Clessi, que, por passado, não deixava de ser tão memória quanto o seu. Agora, qual desses é o passado real?

Essa ideia de tempos que se entrecruzam sob vários planos de ação, antes de digressões temporais, são a própria condição para se evocar a virtualidade e os enganos da memória, podendo ser interpretada, inclusive, como uma alegorização do tempo real, intransponível para o tempo narrativo do espetáculo. Alegoria ainda provocada pela própria iluminação, que, ao intercalar ou fundir os planos de ação do espetáculo, confunde as instâncias de verdade e falsidade discursiva, pois faz com que o plano memorialístico, e mesmo o da realidade, sejam crivados pelo plano da alucinação. Onde um termina e o outro começa? Como distingui-los se é a partir da conversa que Alaíde 
tem com Madame Clessi no plano da alucinação que se dá o processo de rememoração?

Ademais, a própria tensão criada entre a profusão de vários tempos e vários momentos contíguos acaba por presentificar angústias e inquietações típicas ao momento em que vive a personagem. Isso faz com que acordemos para o fato de que, embora narre a sua própria história - do que se pressupõe um narrador que sabe o que realmente aconteceu, uma vez que depõe sobre si mesmo -, Alaíde é uma personagem em cujo grau de incertezas reverbera tão forte que nem mesmo acerca de si poderá traçar qualquer afirmação válida, que não possa ser contradita depois. Sua memória, como o comentário rodrigueano nos adianta, está “em franca desagregação. Imagens do passado e do presente se confundem e se superpõem. As recordações deixaram de ter ordem cronológica" (RODRIGUES, 1977, p. 62). Tanto que Clessi a advertirá: "Você está fazendo uma confusão! Casamento com enterro! [...] Moda antiga com moda moderna! Ninguém usa mais aquele chapéu de plumas, nem aquele colarinho!"; ao passo que Alaíde se justificará: “Tudo está tão embaralhado na minha memória! Misturo coisa que aconteceu e coisa que não aconteceu. Passado com o presente. (num lamento) É uma misturada!" (RODRIGUES, 1977, p. 80, grifos do autor). Enfim, não lhe cabe mais a onisciência e a onipresença de um narrador que tudo sabe, tudo vê e em tudo guia os rumos de suas criaturas. É algo como se a personagem rodrigueana colocasse a si própria "como quem duvida, interroga e procura, como se a verdade acerca de suas personagens [e até de si mesma] não lhe fosse mais bem conhecida que as próprias personagens ao leitor [ou, no seu caso, espectador]" (AUERBACH, 2004, p. 482).

E se digo narrador, é porque no momento em que Alaíde se põe a rememorar, se põe igualmente a narrar os acontecimentos de que se recorda, tendo inclusive, direito à intervenção e ao comentário sobre sua personagem, como sua voz no microfone posicionando-se acerca dos acontecimentos do plano da memória deixa evidenciar. Isso traz ainda outra inovação da mîse en cène rodrigueana, que rejeita não só a tragédia, como a própria forma dramática em si, que pressupunha, desde Aristóteles (1997, p. 24), "atores agindo, não narrando" suas emoções. Não quero dizer, por isso, que Vestido de noiva esteja muito mais próximo ao épico que ao dramático. De fato, o tipo de narração que se apresenta em autores como Brecht, por exemplo, é bastante diferente daquele que se verifica em Vestido de noiva, o qual nos leva inclusive a um caráter de identificação, que embora não se exclua do épico, está longe do distanciamento a que este se propõe. Também não quero dizer que essa característica de narração pela rememoração seja substancialmente nova: até o coro na tragédia antiga às vezes assumia o papel de narrador, apresentando as personagens, comentando-as. No entanto, o caso é que a atitude dessa Alaíde narradora é que é essencialmente diferente do que se fizera até então, pois ao invés de pretender revelar a verdade de suas personagens e de si, admitirá um pensamento confuso, aberto, que não pode saber o lugar do outro, e que recompõe o mundo com as recordações com que quer preenchê-lo, não admitindo lembranças que, como as da irmã acerca de seu noivo, lhe desagradassem: "Eu não admito que você venha recordar essas coisas! Ele é meu noivo!" (RODRIGUES, 1977, p. 57). É isso que faz com que duvidemos da matéria narrada, sobretudo porque existe o predomínio dos planos da memória e da alucinação, que faz com que ao invés de o plano da realidade ser-lhes o filtro, inverta-se a ordem tradicional: é o plano da realidade que será filtrado pelos planos da memória e da alucinação.

Assim, se no começo acreditamos desvendar o mistério com o fim da peça; depois, nos damos conta de que o mistério não há como ser revelado. Primeiro porque não há uma delimitação suficientemente plástica para que possamos definir Alaíde ou mesmo o espaço em que circunda. Segundo, porque se, como memória, ela tem tempo para reelaborar o acontecido, quem garante que a sua visão é a revelação do que de fato aconteceu? Ela própria admite a parcialidade de sua visão das coisas, que sempre lhe surgem sem rosto, como no caso da irmã, ou na multiplicação deles, como ocorrera ao rosto do marido; e isto quando lhe surgem, afinal, sua memória 
andava tão ruim, tão confusa e misturada. Terceiro, porque a multidivisão dos tempos e dos espaços pode ser interpretada como loucura da personagem, ou mesmo como desconstrução de uma realidade una. E, por fim, quarto, porque se é a própria personagem a admitir-se louca: "Alaíde - (impressionada) Sou louca? (com doçura) Que felicidade!" (RODRIGUES, 1977, p. 15, grifos do autor), não estaria a loucura a isentar-lhe de quaisquer compromissos com o real? Ademais, se é esta mesma personagem que afirmava lembrar-se "direitinho, direitinho" (RODRIGUES, 1977, p. 30) de ter matado o marido, a admitir que "às vezes, pode ter sido sonho!" (RODRIGUES, 1977, p. 95), quem garante que os acontecimentos posteriores no plano da memória aconteceram na realidade? E se aconteceram, por que não vieram expressos nesse plano? Mais: Alaíde não misturava tempos e histórias em sua mente (?):

Alaíde - (microfone) Você está vendo, Clessi? Outra vez. Penso que estou contando o seu caso, contando o que li nos jornais daquele tempo sobre o crime, e quando acaba, misturo tudo! Misturo Traviata, ... E o vento levou..., com o seu assassínio! Incrível. (pausa) Não é? (RODRIGUES, 1977, p. 106, grifos do autor).

O que a impediria, então, de estar misturando tudo mais uma vez?

Destarte, o desfecho da peça revela que o reconhecimento não se dá, como naquele Édipo, pela revelação da verdade, mas pela perseguição de uma verdade, que ao invés de iludir, pede, desde a sua gênese, desculpas por ter nascido. De um lado, na tragédia antiga, e na moderna também - pela permanente estruturação trágica de seu enredo -, o que temos são fenômenos acabados, inteiros, uniformemente iluminados, definidos temporal e espacialmente, ligados entre si sob um único plano onde tudo (supostamente) é dado a conhecer: pensamentos e sentimentos expressos; nada aparece sem que lhe seja notado e explicado ao espectador - vide Édipo, que mesmo no momento de desespero e sofrimento que é para ele o reconhecimento, não deixa de anunciar exornada e ordenadamente que furará seus olhos e viverá sozinho para o resto de seus dias. A explicação do mordomo da peça de Salacrou mais uma vez também nos servirá como exemplo, já que não estará muito longe disso. Do outro lado, na tragédia moderna de que a obra rodrigueana é exemplo, temos a rapidez do despojado resumo (CALVINO, 2006), onde só é iluminado aquilo que interessa à meta da ação, o restante fica na escuridão. O que há entre as ações é inconsistente; tempo e espaço são indefinidos e precisam de interpretação; os pensamentos e os sentimentos permanecem quando não inexpressos, sugeridos pelo silêncio ou pelo discurso fragmentário. O todo permanece enigmático e qualquer tentativa de fechar o texto estará fadada ao insucesso.

O que quero dizer com isso não é que o texto elimine qualquer possibilidade de verossimilhança. $\mathrm{E}$ talvez a este respeito me fosse necessário diferençar os dois tipos de verossimilhança que me interessam. Em um primeiro nível, falo da verossimilhança interna, entre o texto do dramaturgo e a encenação do espetáculo, onde não só a palavra, como tom de voz, gesto, expressão facial e corporal, movimento cênico, maquiagem, vestuário, cenário, iluminação, música, tudo enfim, dentro de uma rede de signos altamente funcionais, ajudam a compor a significação. É o que poderemos atestar, por exemplo, com a iluminação e o cenário - dos quais já falei aqui. E não só. O que dizer da alternância entre o barulho de derrapagem e dos vidros se quebrando simulando um acidente? E da música: a marcha fúnebre e a nupcial? Não ajudariam a compor o suspense da peça, uma vez que se recomeçam e se interrompem, vêm aos pedaços, tais como as lembranças de Alaíde? A propósito do andar frenético da personagem nos momentos de aflição: não ajudam a compor seu desespero? O fato é que "a arte do espetáculo é, entre todas as artes e, talvez, entre todos os domínios da atividade humana, aquela onde o signo manifesta-se com maior riqueza, variedade e densidade" (GUINSBURG, 1988, p. 97), onde não só a palavra significa, mas tudo o que no palco nos é revelado: não à toa é que Rodrigues coloca em seu texto, entre parênteses, o tom de voz, as reações, os movimentos que quer que os atores façam para indicar o sentido pretendido. 
Agora, no que diz respeito ao segundo nível de verossimilhança, que poderíamos chamar de externa, a qual está ligada à recepção do espetáculo, que supostamente precisaria ser inteiro, com princípio, meio e fim, para ser recebido como real, essa não parece existir. O que a peça de Nelson Rodrigues descortina, através de sua representação parcelar e fragmentária, é que a própria plasticidade na busca da descrição o mais verossímil e o mais fiel possível, já trai o seu propósito na tentativa mesma da descrição, pois revela o insucesso já (des)esperado de uma iniciativa que tenta, na fidedignidade e na verossimilhança, escusar-se e iludir quanto à sua natureza eminentemente imaginativa e ficcional. É uma nova mimesis que se verifica, que se outrora esteve ligada ao fardo que foi o real, hoje, está muito mais ligada à crença da impossibilidade mesma da representação, que se revela apenas parcialmente capaz de exprimir a realidade plural, inacabada e em constante transformação que se apresenta diante de nós. Como representar, afinal, o real à deriva, à suspeita de que a linguagem não representa, tal e qual, um real que lhe seria anterior?

É sob essa mesma dúvida que Vestido de noiva se pautará, renunciando, assim, a uma herança realista que, de tão apegada à fidedignidade, tornou, em termos formais, mesmo as tragédias modernas, muito mais próximas que distantes do modelo grego, como já apontava Szondi (2001) aliás. E é essa mesma dúvida que será a responsável por atribuir a Nelson Rodrigues o seu caráter tão inovador. Claro que temos que ter em mente a relatividade de toda inovação, e não podemos nos esquecer de dramaturgos que, tão bons quanto ele, foram responsáveis por introduzir pouco a pouco o caráter de renovação de nosso teatro. Assim é que não poderemos deixar de mencionar autores já citados, como Roberto Gomes, Renato Viana e Paulo de Magalhães. Nenhuma inovação, afinal, surge do nada. Mesmo as rupturas, como já lembrava Valéry (1960), engendram uma retomada à tradição (ainda que esta retomada se dê pela negação).

No entanto, se escolhi justamente Nelson Rodrigues, é porque a sua inovação definitivamente não está nos temas, como a imprensa e a maior parte da crítica deixa sugerir, mas na forma, que não só rompe com paradigmas da tragédia grega, como com paradigmas da própria estrutura dramática. E, não só pela presença da narração. A personagem, como na estrutura épica do teatro, é impelida a atos de conhecimento, é mutável dentro de seu destino; as cenas são fragmentadas, não se configuram dentro da ordenação tradicional do "princípio-meio-fim", e tampouco explicam suas digressões; enfim, tudo simula e ao mesmo tempo desconstrói inteligentemente a inteireza de uma verdade objetiva-factual, o que, claramente, está muito longe da estrutura dramática convencional, para a qual as personagens são pressupostas como conhecidas, e a ordenação dos acontecimentos é o mais linear possível para alcançar a identificação.

Vestido de noiva encontra, assim, um modo diferente de colocar-se em cena, pois antes de organizar-se como um sistema de ideias racionais, interligadas e justificadas graças ao referido fardo do real, ela se organiza como um sistema de imagens, de figuras e de formas. Estas se dirigem não tanto à nossa razão, mas à nossa imaginação, justamente por criarem um mundo que existe apenas enquanto teatro, mas que de nenhuma maneira ao palco se limita, mostrando que ainda há espaço para o espetáculo cujo discurso apresente uma nova beleza: a beleza da dúvida. Dúvida que é reiterada nos momentos finais da peça, quando Pedro e Lúcia, personagens no plano da realidade e que ainda poderiam nos esclarecer acerca de um final, insinuam não só a possibilidade de um crime, mas também sua possibilidade de loucura: Lúcia ouvirá as vozes de Alaíde pelos cantos a dizer que nunca a deixará em paz; e Pedro sugerirá ele próprio sua loucura: quando Lúcia, revoltada, afirma que ele está bêbado, Pedro, sério, retorquirá: "Ou louco... (grave) Não tenho o menor medo da loucura" (RODRIGUES, 1977, p. 125). E esta não os isentaria, como a Alaíde, do compromisso com a realidade?

Ora, ainda haverá os jornais que poderão revelar o fato - o leitor dirá. Mas, não é dessa mesma autenticidade e verdade veiculada pelos jornais que Madame Clessi se questionará, logo no início da peça, quando perg 
Clessi - (inquieta) Seria tão bom que cada pessoa morta pudesse ver as próprias feições! Eu fiquei muito feia?

Alaíde - O repórter disse que não. Disse que você estava linda.

Clessi - (impressionada) Disse mesmo? Mas... (pausa, com o olhar extraviado) E o talho no rosto? (abstrata) Uma punhalada no rosto não é possível! Foi navalhada, não foi? (RODRIGUES, 1977, p. 85).

E o que dizer da mistura de planos no final, quando se iluminam os palcos da memória e da realidade simultaneamente, e a Alaíde do plano da alucinação entrega o buquê à Lúcia, em seu casamento com Pedro?

(Crescendo a música, funeral e festiva. Quando Lúcia pede o bouquet, Alaíde, como um fantasma, avança em direção da irmã, por uma das escadas laterais, numa atitude de quem vai entregar o bouquet. Clessi sobe a outra escada. Uma luz vertical acompanha Alaíde e Clessi. Todos imóveis em pleno gesto. Apaga-se, então, toda a cena, só ficando iluminado, sob uma luz lunar, o túmulo de Alaíde. Crescendo da Marcha fúnebre. Trevas) (RODRIGUES, 1977, p. 131).

Incoerência por Alaíde entregar o buquê à irmã? Loucura? Metáfora de que a profusão dos planos de ação da realidade, da memória e da alucinação não têm como se desvencilhar? Ou ainda, de que a luz incidindo apenas sobre o túmulo de Alaíde representa a ideia de que a única verdade que pode permanecer é a morte, a que todo ser humano está fadado? Afinal, por que respostas se é a dúvida mesma que se pretende instaurar?

Desse modo, também no âmbito da recepção, somos obrigados a romper com o pensamento realista que nos acompanhou durante tanto tempo da história, já implícito no conceito aristotélico de mímesis, juntamente com seus princípios de Beleza, Equilíbrio, Simetria, pois, na nova mî(me)se en cène, mais vale a Dúvida, a Obscuridade e a Liberdade, que não se deixam avaliar com facilidade. E se é a procurar analogias entre "gregos e rodrigueanos" que estivemos aqui, que falemos então de Perseu e o seu cavalo alado, Pégaso. Pégaso, porque como metade cavalo e metade pássaro, representa a dubiedade e complexidade de algo que, como Alaíde, não se pode definir por um epíteto único; o ser humano não é típico e nem plano, mas individual, subjetivo e extremamente complexo, com seu bem e com seu mal. E Perseu, porque o que a atitude de Alaíde inspira é que, à semelhança de Perseu, derrotemos também nós o olhar petrificador da Medusa e vençamos a estaticidade imposta por ele; que cada vez que o olhar do Destino nos condene à pedra, ou no caso de Alaíde, à morte, que não o olhemos nos olhos, que consideremos o mundo sobre outra ótica, outra verdade, mesmo que a da loucura, e partamos, como sua memória em franca desagregação convida, na eterna busca de um outro olhar, ou de - quem sabe? - um novo recomeço.

\section{Referências}

ARISTÓTELES. "Poética”. In: ARISTÓTELES; HORÁCIO; LONGINO. A poética clássica. 7. ed. São Paulo: Cultrix, 1997, p. 19-52.

AUERBACH, Erich. Mimesis: a representação da realidade na literatura ocidental. 5. ed. São Paulo: Perspectiva, 2004 p. 471-498.

BARTHES, Roland. O rumor da língua. São Paulo: Brasiliense, 1988.

BATALHA, Maria Cristina. Nelson Rodrigues e as obsessões da persona. Revista Ipotesi, Juiz de Fora, v. 11, n. 1, p. 39-47, jan./jun., 2007.

CALVINO, Italo. Seis propostas para o próximo milênio. Trad. de Ivo Barroso. São Paulo: Cia. das Letras, 2006. https://doi. org $/ 10.5433 / 2237-4876.1999 v 2 n 1 p 199$

COSTA, Iná. Alaíde Moreira no purgatório. Praga - Revista de Estudos Marxistas II, São Paulo, p. 69-85, 1997.

GUINSBURG, Jacob et al. Semiologia do teatro. São Paulo: Perspectiva, 1988.

LUKÀCS, Georg. A teoria do romance. São Paulo: Duas Cidades; Ed. 34, 2000.

PEREIRA, Maria Helena da Rocha. Prefácio à Poética de Aristóteles. In: ARISTÓTELES. Poética. Trad. de Ana Maria Valente. 3. ed. Lisboa: Fundação Calouste Gulbenkian, 2008. p. 5-31.

RODRIGUES, Nelson. Vestido de noiva. São Paulo: Abril Cultural, 1977.

ROSA, João Guimarães. Grande Sertão: veredas. 2. ed. Rio de Janeiro: José Olympio, 1958. 
SÓFOCLES. Édipo-Rei. Trad. de Jean Melville. São Paulo: Martin Claret, 2005.

SZONDI, Peter. Teoria do drama moderno [1880-1950]. São Paulo: Cosac \& Naif, 2001.

VALÉRY, Paul. Autre Rhumbs. In: VALÉRY, Paul.Oeuvres. Paris: Gallimard, 1960. p. 635-677.

VIDAL, Paulo. Édipo sem complexo, Hamlet edípico. ECOS: Estudos Contemporâneos da subjetividade, Niterói, v. 4, n. 1, p. 76-89, 2014.

Recebido em: 25/4/2017.

Aprovado em: 15/4/2019.

\section{João Felipe Barbosa Borges}

Instituto Federal Fluminense (IFF)

Orcid: https://orcid.org/0000-0002-3536-9495

E-mail: felipebborges@hotmail.com/ifbborges@iff.edu.br Endereço de correspondência: Rua Nossa Senhora das Dores, $\mathrm{n}^{0} 124$ A. Bairro: Granjaria. Cidade: Cataguases. Estado: MG. CEP: 36773-450. 